\title{
Profil Media Pembelajaran di SMP Negeri Se-Kecamatan
}

\section{Tanjungpinang Timur}

\author{
Tree Evryanti $^{1^{*}}$, Erda Muhartati ${ }^{2}$, Bony Irawan $^{3,}$ \\ ${ }^{1,2,3)}$ Program Studi Pendidikan Biologi, FKIP, Universitas Maritim Raja Ali Haji
}

Dikirim: 12 Maret 2019; Diterima: 2 Oktober 2019; Publikasi: Oktober 2019

\begin{abstract}
The aim of this study is to determine the availability, use and difficulties faced by teachers in the use of learning media. This study uses a quantitative approach with a type of descriptive research. The research data was obtained through questionnaire instruments, observation sheets and interview guidelines. Questionnaires and observation sheets to see the use of learning media and interview guidelines are used to determine the availability and difficulties faced by teachers in the use of learning media. Interview data on the availability of instructional media at SMP A and SMP B are adequate and at C SMP is inadequate. Based on the results of the study that in East Tanjungpinang Junior High School, the use of learning media as a whole was $71 \%$ on average fair. The use of learning media in SMP A has an average of $82 \%$ in the good category. The use of instructional media in SMP B has an average of $58 \%$ in the poor category and the use of instructional media in SMPN C has an average of $72 \%$ fair categories. Interview data on difficulties faced by teachers in the use of learning media from all schools in the East Tanjungpinang sub-district have difficulties in making media, lack of time efficiency in making learning media, creativity in making media still low, inadequate media availability.
\end{abstract}

Keywords: Profile of Learning Media, Availability of media, Use of media

ABSTRAK. Penelitian ini bertujuan untuk mengetahui ketersediaan, penggunaan dan kesulitan yang dihadapi guru dalam pemanfaatan media pembelajaran. Penelitian ini menggunakan pendekatan kuantitatif dengan jenis penelitian deskriptif. Data penelitian diperoleh melalui instrumen angket, lembar observasi dan pedoman wawancara. Angket dan lembar observasi untuk melihat penggunaan media pembelajaran dan pedoman wawancara digunakan untuk mengetahui ketersediaan dan kesulitan yang dihadapi guru dalam pemanfaatan media pembelajaran. Data hasil wawancara ketersediaan media pembelajaran di SMPN A dan SMPN B sudah memadai dan di SMPN C kurang memadai. Berdasarkan hasil penelitian bahwa di SMPN Se-Kecamatan Tanjungpinang Timur penggunaan media pembelajaran keseluruhan rata-rata $71 \%$ kategori cukup. Penggunaan media pembelajaran di SMPN A memiliki rata-rata 82\% kategori baik. Penggunaan media pembelajaran di SMPN B memiliki rata-rata 58\% kategori kurang dan penggunaan media pembelajaran di SMPN C memiliki rata-rata $72 \%$ kategori cukup. Data hasil wawancara kesulitan yang dihadapi guru dalam pemanfaatan media pembelajaran dari keseluruhan sekolah di kecamatan Tanjungpinang Timur memiliki kesulitan dalam membuat media, kurangnya efisiensi waktu dalam membuat media pembelajaran, kreatifitas dalam membuat media yang masih rendah.

Kata Kunci : Profil Media Pembelajaran, Ketersediaan, Penggunaan

*Penulis korespondensi

Alamat surel: tree.evryanti@yahoo.com 


\section{PENDAHULUAN}

Proses pembelajaran sebagai salah satu bagian dalam pendidikan memegang peranan penting. Selain memberikan materi pelajaran, guru juga dapat menginternalisasikan nilai moral kepada siswa. Pembelajaran yang berkualitas mengintegrasikan bahan pelajaran, strategi, media pembelajaran, siswa, dan guru. Penggunaan media pembelajaran merupakan salah satu kunci utama guru dalam mencapai tujuan pembelajarannya di kelas yang berdampak pada pembelajaran berkualitas. Apabila pembelajaran berkualitas maka guru hendaknya menggunakan media pembelajaran sehingga pembelajaran akan menjadi menyenangkan sehingga peserta didik mudah menyerap materi pembelajaran.

Media berperan sebagai pembawa pesan dari sumber kepada penerima. Dalam proses pembelajaran, penerima pesan adalah siswa. Pesan yang disalurkan oleh media dari sumber ke penerima yaitu isi pelajaran yang berasal dari kurikulum yang disampaikan oleh guru kepada siswa. Penggunaan media dalam proses pembelajaran dapat merangsang pikiran, perasaan, perhatian, dan kemauan siswa sehingga dapat mendorong terjadinya proses pembelajaran. Melalui media, isi pelajaran akan lebih jelas maknanya karena penyampaian tidak semata-mata komunikasi verbal melalui penuturan kata-kata oleh guru (Puspita, 2016: 2).

Ketersediaan media pembelajaran sangat penting dan berpengaruh terhadap proses pembelajaran serta guru wajib dan berhak untuk menggunakan media yang disediakan oleh lembaga pendidikan seperti yang terurai pada Undang-Undang Nomor 20 tahun 2003 tentang Sistem Pendidikan Nasional Bab XI pasal 40 bahwa tenaga kependidikan berhak memperoleh kesempatan untuk menggunakan sarana, prasarana, dan fasilitas pendidikan untuk menunjang kelancaran pelaksanaan tugas. Proses pembelajaran dalam penggunaan sarana, prasarana dan fasilitas di sekolah oleh guru bertujuan agar indikator dalam pembelajaran dapat tercapai.

Berdasarkan hasil wawancara di sekolah tersebut adalah peneliti wawancarai beberapa guru di SMP Negeri A Tanjungpinang, SMP Negeri B Tanjungpinang, dan SMP Negeri C Tanjungpinang mengenai penggunaan media pembelajaran guru mengatakan 
bahwa guru tersebut jarang menggunakan media pembelajaran pada saat mengajar karena dengan keterbatasan sarana dan prasarana yang tersedia di sekolah. Hambatan lainnya dalam pemanfaatan media pembelajaran guru mengalami kesulitan dengan membuat media yang harus memerlukan waktu yang cukup lama, memerlukan biaya apalagi sekolah tidak mempunyai akses dana, harus mempunyai keterampilan khusus karena tidak semua guru memiliki keterampilan tersebut. Dari hasil pengamatan yang peneliti lakukan ketersediaan media pembelajaran khususnya IPA di SMP Negeri A Tanjungpinang, SMP B Tanjungpinang, SMP C Tanjungpinang kurang memadai. Masih terdapat kekurangan seperti alat-alat laboratorium, mikroskop, buku cetak, torso dengan jumlah siswa yang cukup banyak dalam satu kelas yang berjumlah 35-38 siswa. Jadi guru hanya menggunakan media seadanya yang ada di kelas pada saat mengajar yang sesuai dengan materi pelajaran.

\section{METODE PENELITIAN}

Penelitian ini telah dilaksanakan di SMPN A Tanjungpinang, SMPN B Tanjungpinang dan SMPN C
Tanjungpinang, waktu penelitian pada bulan september. Subjek penelitian yang terlibat adalah guru di sekolah Kecamatan Tanjungpinang Timur berjumlah 6 orang guru. Penelitian ini merupakan penelitian kuantitatif dan pendekatan deskriptif menggambarkan ketersediaan, penggunaan, dan kesulitan yang dihadapi guru dalam pemanfaatan media pembelajaran.

Dalam penelitian ini menggunakan 3 jenis teknik pengumpulan data yaitu instrumen angket, lembar observasi dan wawancara, instrumen angket digunakan untuk mengukur penggunaan media pembelajaran di sekolah Kecamatan Tanjungpinang Timur dengan jumlah 20 butir soal. Kemudian, instrumen lembar observasi untuk melihat langsung apakah guru menggunakan media pembelajaran pada proses mengajar dengan jumlah 11 butir pengamatan. Untuk instrumen pedoman wawancara untuk mengukur kesulitan yang dihadapi guru dalam pemanfaatan media pembelajaran dengan jumlah 20 butir pertanyaan. Kemudian instrumen tersebut divalidasi oleh dosen ahli.

\section{HASIL DAN PEMBAHASAN}

Berikut disajikan tabel hasil data mengenai profil media pembelajaran di 
SMPN Se-Kecamatan Tanjungpinang

Timur.
1. Ketersediaan Media Pembelajaran di SMPN Se-Kecamatan Tanjungpinang Timur.

Tabel 1. Ketersediaan Media Pembelajaran di SMPN Se-Kecamatan Tanjungpinang Timur.

\begin{tabular}{|c|c|c|c|}
\hline No. & Nama Sekolah & Ketersediaan Media Pembelajaran & Jumlah \\
\hline \multirow[t]{8}{*}{1.} & \multirow[t]{8}{*}{ SMPN A Tanjungpinang } & $\begin{array}{l}\text { Media Cetak: } \\
\text { 1. Buku Cetak }\end{array}$ & 38 \\
\hline & & 2. LKS & 38 \\
\hline & & $\begin{array}{l}\text { Media Visual: } \\
\text { 1. Model alat peraga manussia }\end{array}$ & 13 \\
\hline & & 2. Alat praktikum media KIT optik & 6 \\
\hline & & 3. Mikroskop & 25 \\
\hline & & 4. Poster dinding & 7 \\
\hline & & 5. Charta & 15 \\
\hline & & Total media pembelajaran & 142 \\
\hline \multirow[t]{6}{*}{2.} & \multirow[t]{6}{*}{ SMPN B Tanjungpinang } & $\begin{array}{l}\text { Media Cetak: } \\
\text { 1. Buku Cetak }\end{array}$ & 32 \\
\hline & & 2. LKS & 32 \\
\hline & & $\begin{array}{l}\text { Media visual: } \\
\text { 1. Model alat peraga manusia }\end{array}$ & 1 \\
\hline & & 2. Alat praktikum media KIT optik & 2 \\
\hline & & 3. Mikroskop & 3 \\
\hline & & Total media pembelajaran & 70 \\
\hline \multirow[t]{8}{*}{3.} & \multirow[t]{8}{*}{ SMPN C Tanjungpinang } & $\begin{array}{l}\text { Media cetak: } \\
\text { 1. Buku cetak }\end{array}$ & 35 \\
\hline & & 2. LKS & 35 \\
\hline & & $\begin{array}{l}\text { Media visual: } \\
\text { 1. Model alat peraga manusia }\end{array}$ & 5 \\
\hline & & 2. Alat praktikum media KIT optik & 4 \\
\hline & & 3. Poster dinding & 2 \\
\hline & & 4. Mikroskop & 10 \\
\hline & & 5. Charta & 4 \\
\hline & & Total media pembelajaran & 95 \\
\hline
\end{tabular}

Berdasarkan tabel 1 di atas, dapat diambil kesimpulan bahwa Sekolah SMPN A dan SMPN C dilihat dari alatalat laboratorium sudah cukup sesuai dengan ketersediaan di sekolah namun, masih ada beberapa media yang masih kurang seperti media LCD proyektor karena beberapa guru di dua SMPN sering menggunakan media infokus akan tetapi masih kurang tersedia media tersebut. Kondisi dan juga penempatan alat-alat di laboratorium sudah cukup baik dilihat dari data dokumentasi langsung untuk melihat media pembelajaran di sekolah. Namun di 
sekolah SMPN B masih banyak kurang media pembelajaran di laboratorium maupun media lainnya seperti torso, alat peraga yang dibutuhkan dalam proses pembelajaran sehingga penggunaan media pembelajaran di SMPN B dengan hasil kurang. Oleh karena itu agar suatu proses pembelajaran yang akan dituju maksimal dengan yang diharapkan diperlukan sarana dan prasarana yang memadai sehingga proses pembelajaran membuat para peserta didik dapat antusias dan termotivasi untuk mengikuti pelajaran.

Sehingga dengan hal ini didukung dengan pendapat Candra Alfi (2017: 377) bahwa ketersediaan sarana dan prasarana akan mempengaruhi proses pembelajaran apabila sarana dan prasarana yang memadai maka peserta didik tidak mudah jenuh dalam proses pembelajaran maka sebaliknya apabila sarana dan prasarana kurang memadai sehingga siswa akan mudah jenuh pada proses pembelajaran dan membuat rencana pembelajaran akan berjalan dengan baik dan dapat dikembangkan secara optimal.

2. Penggunaan Media Pembelajaran di SMPN Se-Kecamatan Tanjungpinang Timur.
Profil Penggunaan Media Pembelajaran di SMPN Se-Kecamatan Tanjungpinang

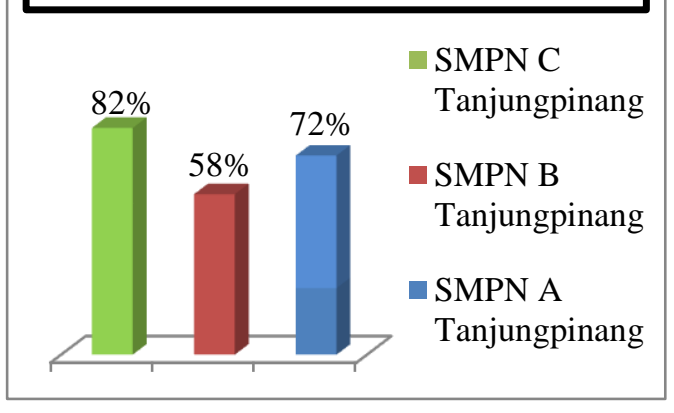

Gambar 1. Profil Penggunaan Media Pembelajaran di SMPN Se-Kecamatan Tanjungpinang Timur.

Berdasarkan gambar 1 di atas, diperoleh data bahwa dari hasil instrumen angket dan lembar observasi di SMPN A Tanjungpinang dari hasil mendapatkan persentase $82 \%$ dengan kategori baik. Hal ini sesuai dengan pendapat Sulistyowati (2015: 84) Media tidak hanya untuk mempermudah guru dalam menyampaikan materi pelajaran dan sebagai alat hiburan bagi peserta didik tetapi juga membantu peserta didik belajar sesuai dengan tujuan yang ingin dicapai. Proses belajar belajar dengan bantuan media pembelajaran dapat mempertinggi kegiatan belajar mengajar siswa sehingga hasil yang didapatkan juga akan lebih baik apabila guru tidak menggunakan media pembelajaran pada proses pembelajaran. Dalam penggunaan media pembelajaran guru juga harus memperhatikan tujuan pembelajaran yang 
hendak dicapai. Sehingga siswa tidak hanya mengerti akan teori pembelajaran tetapi juga dapat mengerti mengaplikasikan secara langsung terhadap media pembelajaran yang digunakan.

Hasil instrumen angket dan lembar observasi di SMPN B Tanjungpinang dari hasil mendapatkan persentase 58\% kategori kurang. Hal ini membuktikan sesuai dengan pendapat dari Dhani Prama (2016: 51) bahwa suksesnya pembelajaran didukung oleh adanya pendayagunaan sarana dan prasarana dan media pembelajaran pendidikan yang ada di sekolah secara efektif dan efisien. Sarana dan prasarana serta media pembelajaran sangat penting di sekolah karena keberadaan media pembelajaran tersebut akan sangat mendukung suksesnya pembelajaran di sekolah terutama guru IPA banyak menggunakan media pembelajaran disetiap materi pembelajaran khususnya yang berhubungan dengan alam dan lingkungan sekitar. Sehingga membuat penggunaan media pembelajaran di sekolah SMPN B Tanjungpinang Timur rentang kategori yang kurang.

Hasil instrumen angket dan lembar observasi di SMPN C Tanjungpinang dari hasil mendapatkan persentase $72 \%$ kategori cukup. Hal tersebut membuktikan bahwa sesuai dengan pendapat Azis (2014: 50) bahwa kompetensi guru dalam menggunakan media pembelajaran komunikasi yang baik ditentukan oleh kesesuaian media pembelajaran yang digunakan oleh pengirim pesan dengan pesan itu sendiri. Oleh sebab itu, komunikator hendaknya menggunakan media sesuai dengan pesan yang akan disampaikan sehingga media pembelajaran yang digunakan mudah dipahami oleh peserta didik dengan baik. Kesalahan dalam pemilihan atau kurangnya dalam penggunaan media pembelajaran akan terjadi tidak tersampainya penggunaan media pembelajaran dengan baik. Agar supaya mendapatkan hasil yang diperoleh secara maksimal maka media pembelajaran harus direncanakan dengan baik maka hasil yang diperoleh juga akan baik. Sebagian besar guru menggunakan media pembelajaran atas dasar pertimbangan bahwa. Merasa sudah akrab dengan media yang digunakan, media yang dipilih guru dapat menggambarkan lebih baik dari guru itu sendiri, media yang dipilih dapat menarik minat serta perhatian siswa dan dapat menuntun siswa pada penyajian yang lebih struktur. 


\section{Kesulitan yang dihadapi guru IPA Pembelajaran. dalam Pemanfaatan Media}

Tabel 2. Kesulitan yang dihadapi guru IPA dalam Pemanfaatan Media Pembelajaran

\begin{tabular}{|c|c|c|}
\hline No. & Nama Sekolah & $\begin{array}{l}\text { Kesulitan yang dihadapi guru IPA dalam pemanfaatan media } \\
\text { pembelajaran }\end{array}$ \\
\hline 1. & SMPN A Tanjungpinang & $\begin{array}{l}\text { 1. Masih melewati alokasi waktu dalam menggunakan media } \\
\text { pembelajaran tetapi guru masih berupaya agar bisa membuat } \\
\text { media sendiri. }\end{array}$ \\
\hline 2. & SMPN B Tanjungpinang & $\begin{array}{l}\text { 1. Masih melewati alokasi waktu dalam menggunakan media } \\
\text { pembelajaran sehingga guru tidak dapat membuat media } \\
\text { sendiri sesuai dengan alokasi waktu. } \\
\text { 2. Kurangnya pelatihan dalam pemanfaatan media sehingga } \\
\text { guru merasakan kesulitan dalam membuat media sendiri. } \\
\text { 3. Kurang memiliki kreatifitas dalam pemanfaatan media } \\
\text { pembelajaran. } \\
\text { 4. Masih membutuhkan waktu yang lama dalam pemanfaatan } \\
\text { media pembelajaran yang menarik. } \\
\text { 5. Kesulitan karena ketersediaan media pembelajaran yang } \\
\text { masih kurang lengkap. } \\
\text { 6. Kesulitan dalam memilih media sesuai dengan situasi dan } \\
\text { kondisi sekolah. }\end{array}$ \\
\hline 3. & SMPN C Tanjungpinang & $\begin{array}{l}\text { 1. Masih melewati alokasi waktu dalam menggunakan media } \\
\text { pembelajaran dari } 2 \text { guru hanya } 1 \text { saja yang masih berupaya } \\
\text { dalam membuat media sendiri yang disesuaikan dengan } \\
\text { alokasi waktu yang ditentukan. } \\
\text { 2. Masih kesulitan dalam pemanfaatan media pembelajaran } \\
\text { karena kurangnya pelatihan yang lebih khusus. } \\
\text { 3. Kurang memiliki kreatifitas dalam pemanfaatan media } \\
\text { pembelajaran tetapi masih ada guru yang berupaya agar } \\
\text { sebisa mungkin membuat media yang menarik. } \\
\text { 4. Kurangnya akses dana dari sekolah. }\end{array}$ \\
\hline
\end{tabular}


Dari hasil wawancara dibeberapa sekolah di Kecamatan Tanjungpinang Timur. Pertama di SMPN A Tanjungpinang Timur guru tersebut mengatakan bahwa dari 2 guru yang diwawancarai guru tersebut pernah membuat media sendiri tetapi memiliki kesulitan dalam waktu untuk membuatnya karena membuat media yang menarik yang bisa membuat siswa merasakan media tersebut bisa menarik perhatian untuk lebih aktif dengan menggunakan media pembelajaran tersebut. Tidak terlalu banyak kesulitan yang dihadapi guru IPA di sekolah SMPN A Tanjungpinang Timur hal ini sesuai dengan pendapat menurut Hasan (2015: 46) menggunakan media pembelajaran seperti alat peraga di sekolah apabila media pembelajaran tidak tersedia di sekolah guru berupaya berinisiatif akan membuat sendiri bisa dibantu dengan siswa. Sebagian guru juga berupaya dapat membuat sketsa dipapan tulis agar siswa lebih mudah memahami apabila tidak ada media yang digunakan.

Selanjutnya, di SMPN B dan SMPN C sama halnya didua sekolah ini bahwa dengan hasil penggunaan media pembelajaran dengan rentang kategori cukup dan kurang hal ini berarti bahwa di SMPN B dan SMPN C dari hasil wawancara yang dilakukan oleh peneliti guru jarang sekali membuat media sendiri halnya karena membutuhkan waktu yang lama, merepotkan karena harus memiliki kreatifitas yang tinggi dari beberapa guru di sekolah tersebut kurangnya kreatifitas dalam membuat media pembelajaran yang menarik. Sejalan dengan pendapat Alwi (2017: 159) kreatifitas adalah proses yang digunakan seseorang untuk mengekspresikan sifat dasarnya menghasilkan suatu bentuk dan produk yang mengkomunikasikan kepada orang lain. Sehingga kreatifitas menjadi sangat pribadi sifatnya karena kreatifitas menjadi diri sendiri. Kreatifitas guru dalam pemanfaatan media pembelajaran karena berkaitan dengan pemilihan media pembelajaran apabila pemilihan media tidak sesuai maka pemanfaatan media serta penggunaan media pembelajaran tidak akan maksimal dan hasilnya juga tidak tercapai. Sehingga guru hanya masih menggunakan media yang tersedia di sekolah akan tetapi ketersediaan media pembelajaran di sekolah yang kurang memadai sehingga guru hanya menggunakan papan tulis, buku cetak dan LKS sebagai media pembelajaran.

Dapat disimpulkan bahwa dalam penelitian ini dari ketersediaan media pembelajaran yang masih ada ketersediaan media di sekolah yang kurang memadai, dari penggunaan media pembelajaran pada saat mengajar masih ada guru yang tidak menggunakan media pembelajaran yang membuat proses pembelajaran menjadi lebih aktif dan menyenangkan, dari kesulitan yang dihadapi guru IPA dalam pemanfaatan media pembelajaran memiliki kesulitan dalam membuat media, kurangnya efisiensi waktu dalam membuat media pembelajaran, kreatifitas dalam membuat media yang masih 
rendah, ketersediaan media yang kurang memadai.

Kemudian, implikasi yang dapat diberikan oleh penelitian ini adalah ketersediaan, penggunaan dan kesulitan yang dihadapi guru dalam pemanfaatan media pembelajaran agar guru perlu menciptakan suasana belajar yang aktif dan menyenangkan dengan menggunakan media pembelajaran pada saat proses pembelajaran serta sekolah dan dinas terkait perlu menyediakan media pembelajaran sehingga adanya tanggung jawab untuk menyediakan media pembelajaran yang lebih banyak dan menarik. Sehingga peserta didik akan lebih mudah untuk memahami materi yang diajarkan oleh pendidik.

\section{KESIMPULAN DAN SARAN}

Berdasarkan hasil penelitian dapat disimpulkan bahwa:

1. Ketersediaan media pembelajaran di SMPN A sudah memadai seperti alat-alat laboratorium, media visual seperti alat peraga, poster, charta akan tetapi masih ada beberapa media yang kurang seperti LCD proyektor yang biasa sering digunakan oleh guru. Ketersediaan media pembelajaran di SMPN B masih banyak yang kurang dari media cetak seperti buku cetak, LKS. Media visual seperti alat peraga, poster, charta. Alat-alat laboratorium kurang lengkap. Ketersediaan media pembelajaran di SMPN C sudah memadai seperti alat-alat laboratorium, media visual seperti alat peraga, poster, charta akan tetapi masih ada beberapa media yang kurang seperti LCD proyektor yang biasa sering.

2. Penggunaan media pembelajaran di SMPN A Tanjungpinang Timur berada pada persentase $82 \%$ kategori baik. Penggunaan media pembelajaran di SMPN B Tanjungpinang Timur berada pada persentase $58 \%$ kategori kurang. Penggunaan media pembelajaran di SMPN C Tanjungpinang Timur berada pada persentase $72 \%$ kategori cukup.

3. Kesulitan yang dihadapi guru IPA dalam pemanfaatan media pembelajaran di SMPN A, SMPN B, SMPN C bahwa dalam memanfaatkan media pembelajaran masih memiliki kesulitan karena kurangnya pelatihan, kreatifitas rendah, masih membutuhkan waktu yang lama, masih melewati alokasi waktu dalam menggunakan media pembelajaran, kesulitan dalam memilih media sesuai dengan situasi dan kondisi sekolah, kurangnya akses dana dari sekolah.

Berdasarkan analisis, pembahasan, dan kesimpulan sebelumnya maka peneliti memberikan saran kepada beberapa pihak, diantaranya sebagai berikut:

1. Bagi dinas pendidikan

Hendaknya memberikan pelatihanpelatihan terhadap guru terkait penggunaan, pemanfaatan media pembelajaran sehingga guru akan terbiasa menggunakan serta membuat media dengan sendir tidak hanya menggunakan media pembelajaran yang berada di sekolah. Jadi guru tidak merasa 
kesulitan dalam memanfaatkan media pembelajaran. Sebaiknya dinas dapat memfasilitasi media pembelajaran yang ada di sekolah yang masih banyak membutuhkan media pembelajaran.

\section{Bagi guru}

$$
\text { Bagi guru diharapkan sebaiknya }
$$
menggunakan media pembelajaran. Guru hendaknya memiliki inisiatif dalam menggunakan media pembelajaran serta media pembelajaran yang dilakukan hendaknya bervariasi. Dalam pemanfaatan media pembelajaran hendaknya guru dapat membuat media pembelajaran yang menarik sehingga tidak mengalami kesulitan dalam memanfaatkan media pembelajaran. Guru juga dapat mengajukan kepada kepala sekolah dalam pelatihan penggunaan, pemanfaatan media pembelajaran. Serta guru bisa mengajukan kepada kepala sekolah terhadapat ketersediaan media pembelajaran yang masih banyak kekurangan.

3. Bagi peneliti lain

Bagi peneliti lain yang ingin melakukan penelitian tentang profil media pembelajaran maka dapat mengembangkan instrumen yang lebih baik lagi agar dapat membantu peneliti mengetahui profil media pembelajaran lebih mendalam. Seain itu, penelitian ini dapat dijadikan landasan untuk melanjutkan penelitian dimasa yang akan datang guna mengetahui profil media pembelajaran.

\section{DAFTAR PUSTAKA}

Alwi, S. 2017. Problematika Guru dalam Pengembangan Media Pembelajaran. Jurnal
Pendidikan. 10 oktober 2018. 8(2). http://www.ejurnal.iainlhokseumawe.ac.id

Azis, A. 2014. Kompetensi Guru dalam Penggunaan Media dengan Mutu Pembelajaran. Jurnal Pendidikan. 10 oktober 2018. 5(1).50-56. http://www.stkippgrismp.ac.id./backsiteconten t/uploads/2014/03/Jurnal-Vol.5Abdul-Azis.

Candra, A. 2017. Tinjauan Ketersediaan Sarana dan Prasarana Pembelajaran Pendidikan Jasmani dan Kesehatan di SMP Negeri Se-Kecamatan Perhentian Raja Kabupaten Kampar. Jurnal Primary. 10 september 2018 6(1). http://www.258250tinjauan-ketersediaan-sarana-dan-prasara9f6f $47 \mathrm{~cd} . p d f$.

Dhani, D. 2016. Survey Ketersediaan dan Penggunaan Sarana dan Prasarana Pembelajaran olahraga di Sekolah Menengah Pertama Sekota Ngawi ditinjau dari Status Sekolah. Jurnal Sportif. 20 agustus 2018 . 2(2). http://www.ojs.unpkediri.ac.id.

Hasan, H. Kendala yang Dihadapi Guru dalam Proses Belajar Mengajar Matematika di SD Negeri Kabupaten Aceh Besar. Jurnal Pesona Dasar. 15 oktober 2018. 1 (4). http://www.jurnal.unsyiah.ac.id/PEAR/article/ download/7524/6192. ISSN: 2337-9227.

Permendiknas. Nomor 20 Tahun 2003. Tentang Sistem Pendidikan Nasional Bab XI pasal 40 Tenaga Kependidikan Berhak Memperoleh Kesempatan untuk Menggunakan Sarana, Prasarana, dan Fasilitas Pendidikan. Jakarta: 2003. h.2.

Sulistyowati., D.A. 2015. Penggunaan Media Pembelajaran oleh Guru Pada Program Keahlian Administrasi Perkantoran di SMK Negeri 7. Skripsi. Universitas Negeri Yogyakarta. Yogyakarta.

Puspita, A.D. 2016. Analisis Ketersediaan Kondisi, dan Penggunaan Media Pembelajaran IPA di Kelas Tinggi SDN Lumbir Kecamatan Lumbir Kabupaten Banyumas. Skripsi. Universitas Negeri Semarang. Semarang. 